\title{
1 Phosphate Nutrition and Defoliation Effects on Growth and Root Physiology of Alfalfa
}

4 Synan F. Abu Qamar, Suzanne M. Cunningham, and Jeffrey J. Volenec

5

Department of Agronomy, Purdue University, West Lafayette, Indiana, USA

8 Address correspondence to Jeffrey J. Volenec, Department of Agronomy, Purdue University, 9 915West State St., West Lafayette, IN 47907-2054, USA. E-mail: jvolenec@ purdue.edu

\section{Abstract}

Phosphorus (P) deficiency reduces forage yield and stand persistence of alfalfa (Medicago sativa L.). The objective of this study was to determine the influence of $\mathrm{P}$ nutrition and defoliation on alfalfa shoot growth, root carbohydrate and protein metabolism, and steady-state mRNA levels for high-affinity $\mathrm{P}$ transporters. In a greenhouse study, $\mathrm{P}$ deprived plants were provided with 0 , 0.25, 2, and $6 \mathrm{mM} P$ beginning $7 \mathrm{~d}$ before shoot removal. Plants were sampled immediately (day -7) on days -5, -2, 0 (day of shoot removal), and on days 1, 2, 6, and 9 post-shoot removal.

Addition of P to P-deficient plants stimulated growth of shoots but not roots. Taproot bark sugar

(1)
concentrations were reduced significantly in cut plants at any rate of $\mathrm{P}$, whereas only the $6 \mathrm{mM} \mathrm{P}$ treatment reduced taproot wood sugar concentrations in uncut plants. There was a significant defoliation-induced decline in both wood and bark sugar and amino-acid concentration that was enhanced at high $\mathrm{P}$ rates. Low $\mathrm{P}$ reduced utilization of starch and protein reserves in taproots. Transcripts for a high-affinity P transporter were not detected in any root or shoot tissue assayed, irrespective of defoliation or $\mathrm{P}$ treatment. The uncertain relationship between $\mathrm{P}$ availability and P-transporter transcript abundance in our greenhouse-grown plants requires additional

Key words: phosphate nutrition, Medicago sativa L., phosphate transporter, defoliation, 
33 Phosphorus (P) application increases forage yield and persistence in alfalfa (Medicago sativa L.), and it is generally believed that this nutrient does so, in part, by having a positive impact on taproot reserve accumulation and use. Decreases in leaf photosynthesis and reduced accumulation of total nonstructural carbohydrate (TNC) in roots have been documented in Pdeficient plants (Brooks, 1986). Rao et al. (1990) suggested that tissue P concentration was directly related to export of sugar out of chloroplasts of sugar beet (Beta vulgaris L.). They reported that plants grown under P deficiency exported 67\%-87\% less carbon (C) than plants receiving adequate $\mathrm{P}$. They also stated that photosynthate production was not reduced as dramatically as $\mathrm{C}$ export under $\mathrm{P}$ deficiency, resulting in the accumulation of $\mathrm{C}$ as starch in source leaves. Li et al. (1998) related the slow shoot regrowth of defoliated, P-deficient alfalfa plants to decreased starch mobilization in taproots, and slow sugar export from roots to developing shoots. Plants that were P-deficient contained high levels of taproot starch, but these concentrations were unchanged after defoliation, suggesting that starch use is severely impaired by $\mathrm{P}$ deficiency in taproots of this species.

Cunningham and Volenec (1996) identified three vegetative storage proteins (VSPs) that are preferentially utilized as a source of $\mathrm{N}$ for shoot regrowth. Understanding the role theseNpools play in alfalfa shoot regrowth and how this process interacts with $\mathrm{P}$ nutrition is vital for alfalfa improvement efforts aimed at increasing persistence and forage yield. The influence of $\mathrm{P}$ fertilization on protein accumulation and utilization has also been examined. Rufty et al. (1993) suggested that lower protein accumulation in P-deficient soybean (Glycine max (L.) Merr.) was associated with decreased tissue nitrogen $(\mathrm{N})$ concentration, possibly due to low N2-fixation. Li et al. (1998) observed alfalfa taproot protein accumulation under P-limiting conditions, but utilization of these taproot proteins as a source of $\mathrm{N}$ for regrowing shoots after defoliation was markedly reduced compared with taproots under adequate $\mathrm{P}$ conditions. Therefore, $\mathrm{P}$ nutrition appears to influence both the accumulation and subsequent use of root organic reserves in alfalfa. Recently, improved nutrient uptake through specialized transport mechanisms has been Examined in plants. Muchhal and Raghothama (1999) identified a protein involved in improving

62 for this high-affinity $\mathrm{P}$ transporter increased in tomato (Lycopersicon esculentum Mill.) roots 
subjected to low $\mathrm{P}$ concentrations when compared with roots of plants grown in high-P media. Amino-acid sequencing revealed that the protein is probably associated with the plasma membrane, and most likely plays a role in $\mathrm{P}$ transport into cells. Transcriptional regulation by negative feedback of the Phtl family of plant P-transporters occurs in roots. Expression studies with genes encoding AtPT1 and AtPT2 P-transporters of mouse ear cress (Arabidopsis) have shown that they are preferentially expressed in roots and that their expression is considerably enhanced by P deprivation (Smith et al., 1997). Upon re-supply of P to P-deprived plants, the expression of the AtPT1 and AtPT2 genes was downregulated and the steady-state mRNA levels corresponding to these two genes decreased rapidly. Many of the expression studies on genes encoding root $\mathrm{P}$ transporters isolated from tomato, potato (Solanum tuberosum) and barrel medic (Medicago truncatula (Gaertn.)) have indicated that high-affinity P-transporters in these species are similarly regulated by external P concentrations (Leggewie et al., 1997; Liu et al., 1998a, 1998b).

Split-root studies indicate that $\mathrm{P}$ uptake rates by roots deprived of $\mathrm{P}$ responded to the overall $\mathrm{P}$ status of the plant rather than to the localized external $\mathrm{P}$ concentration adjacent to that section of the root (Drew and Saker, 1984). This response has been confirmed using molecular studies that indicate transcriptional regulation of $\mathrm{P}$-sensitive genes reflects whole-plant $\mathrm{P}$ status, and not localized P levels in P-deprived tissues or organs (Liu et al., 1998b). Feedback regulation of P uptake into plant roots is, therefore, a systematic rather than a localized response.

Because $\mathrm{P}$ is a key element for alfalfa growth and agronomic performance, it is important to understand its role in alfalfa root physiology. The first hypothesis of this study was that $\mathrm{P}$ deficiency limits root reserve accumulation and use in alfalfa, particularly sugar, amino-N, protein, and tissue $\mathrm{P}$ concentrations, which, in turn, limits shoot regrowth rates, and ultimately, forage yield. The second hypothesis was that the expression of high-affinity P-transporters is enhanced in taproots of P-stressed alfalfa, and that this steady-state transcript level is reduced by herbage removal. The objective of this studywas to determine the influence of $\mathrm{P}$ nutrition and defoliation on alfalfa shoot growth, root carbohydrate and protein metabolism, and steady-state mRNA levels for high-affinity $\mathrm{P}$ transporters. 
MATERIALS AND METHODS

95 Plant Culture and Tissue Sampling

96

97

98

99

100

101

102

103

104

105

106

107

108

109

110

111

112

113

114

115

116

117

118

119

120

121

122

123

124

Alfalfa (cv 5454) seeds were sown in $1 \mathrm{~L}$ pots containing coarse river sand at a density of 10-12 seeds per pot. Pots were placed in a greenhouse with a photoperiod extended to $15 \mathrm{~h}$ using incandescent and fluorescent lights $\left(160 \mu\right.$ mole $\left.\mathrm{m}^{-2} \mathrm{~s}^{-1}\right)$. Air temperature varied from $22 \circ \mathrm{C}$ to $32{ }^{\circ}$ C. Seeds were inoculated with Rhizobium melitoti (Liphatech Inc., Milwaukee, WI) and were fertilized three times weekly with minus-N, minus-P Hoagland's solution modified to contain 0 mM P by substituting $\mathrm{K}_{2} \mathrm{CO}_{3}$ for $\mathrm{KH}_{2} \mathrm{PO}_{4}$ (Hoagland and Arnon, 1950). Plants were defoliated to a $4 \mathrm{~cm}$ stubble at full bloom $90 \mathrm{~d}$ after planting and thereafter grown for two defoliationregrowth cycles of $35 \mathrm{~d}$ each. Plants were provided reverse-osmosis purified water as needed. After the second defoliation, pots within replicates were randomized and three times weekly received $100 \mathrm{~mL}$ minus-N minus-P Hoagland's solution modified to contain $0 \mathrm{mM} \mathrm{P}$ as described above. Beginning on day 28 of the second regrowth cycle (denoted as day -7) plants were fertilized three times weekly with $100 \mathrm{~mL}$ minus-N Hoagland's solution modified to contain $0,0.25,2$, or $6 \mathrm{mM}$ P. As before, $\mathrm{K}_{2} \mathrm{CO}_{3}$ concentration was adjusted in order to maintain constant solution K concentrations. Plants were sampled immediately after application of varied P treatments (day -7), and on days -5 and -2 prior to the third and final defoliation (day 0 ). These times represent days 30 and 33, respectively, of the second regrowth cycle. Plants were defoliated for the third time on day 35, and sampled immediately (day 0) or 1, 2, 6 and $9 \mathrm{~d}$ later. Undefoliated plants were also sampled on day 9 (denoted as $9 \mathrm{U}$ after defoliation on figures) and served as uncut controls. At each sampling, roots were washed free of sand under cold tap water and separated into wood, bark, and fine root tissues. Root tissues were diced, mixed, and split into two fractions, one that was immersed in liquid N2 for RNA analysis, and one that was frozen on solid CO2 for protein and carbohydrate analyses. All tissues were ground to pass a 1$\mathrm{mm}$ screen and stored at $-80^{\circ} \mathrm{C}$ for analysis. Shoot tissues collected at day 0 and shoot and root tissues collected at Day 9 after the third defoliation were dried at $65^{\circ} \mathrm{C}$ and weighed.

\section{Root Biochemical Analyses}

Sugars were extracted from $30 \mathrm{mg}$ ground fresh bark and wood-root tissues with $1 \mathrm{~mL}$ of 800 $\mathrm{mL} \mathrm{L}^{-1}$ ethanol and analyzed with anthrone as previously described, using glucose as a standard (Cunningham and Volenec, 1998; Koehler, 1952). The ethanol-extracted residue was dried at 
$55^{\circ} \mathrm{C}$, resuspended in $500 \mathrm{Ml}$ of deionized water, and placed in a boiling water bath for $10 \mathrm{~min}$ to gelatinize starch. Starch was hydrolyzed enzymatically and glucose analyzed as described previously (Cunningham and Volenec, 1998). All protein analysis procedures were conducted at temperatures between $0{ }^{\circ} \mathrm{C}$ and $4{ }^{\circ} \mathrm{C}$. Soluble proteins were extracted by suspending $30 \mathrm{mg}$ of fresh bark and wood root tissues in $1 \mathrm{~mL}$ of $100 \mathrm{mM}$ sodium phosphate buffer $(\mathrm{pH}$ 6.5) containing $1 \mathrm{mM}$ phenylmethylsulfonylfluoride and $10 \mathrm{mM}$ 2-mercaptoethanol as described (Cunningham and Volenec, 1998). The resulting supernatant was analyzed for soluble protein using bovine albumin serum as a standard (Bradford, 1976). Amino acids were extracted by suspending $30 \mathrm{mg}$ of fresh bark and wood-root tissues in $1 \mathrm{~mL}$ of $100 \mathrm{mM}$ sodium phosphate buffer (pH 6.8) containing $10 \mathrm{mM} 2$-mercaptoethanol. Colorimetric analysis of amino acids in the supernatant was performed using ninhydrin, with glycine as a standard (Rosen, 1957).

\section{Tissue Phosphorus Analysis}

Ground root wood, root bark, fine roots, leaf, and stem tissues, (150 to $200 \mathrm{mg}$ fresh wt.) were digested in $5 \mathrm{~mL}$ of $18 M \mathrm{HNO} 3$ in $50 \mathrm{~mL}$ digestion tubes. Volumes were adjusted to $35 \mathrm{~mL}$ with double deionized water and samples mixed. Total P was determined colorimetrically (Chen et al., 1956).

\section{RNA Extraction and Northern Analysis}

Total RNA was isolated from $2 \mathrm{~g}$ of fresh powdered wood, bark, fine roots, and leaf and stem tissues, and ground with a mortar and pestle in liquid $\mathrm{N}_{2}$ using the hot phenol method (Gana et al., 1998). Total RNA (20 $\mu \mathrm{g}$ ) was separated on $1.5 \%$ agarose, $6 \%$ (v/v) formaldehyde gels (Lehrach et al., 1977). The RNA was transferred to Zeta-probe membranes (BioRad, Richmond, CA) after electrophoresis. Membranes were pre-hybridized in $0.12 M \mathrm{Na} 2 \mathrm{HPO} 4(\mathrm{pH} 7.2)$, $7 \%$ SDS, $50 \%(\mathrm{v} / \mathrm{v})$ formamide, $0.25 \mathrm{M} \mathrm{NaCl}$, and $1 M$ EDTA for $4 \mathrm{~h}$ at $42^{\circ} \mathrm{C}$ with slow shaking. The insert from a high-affinity phosphate transporter from Medicago sativa (MsPT1; GenBank accession number AY366351) was ${ }^{32} \mathrm{P}$ labeled using the random primer method (Feinberg and Volgestein, 1983). Hybridization and washing of membranes were performed as described previously (Gana et al., 1998). Membranes were exposed to x-ray film at $-80^{\circ} \mathrm{C}$.

\section{Statistical Analysis}


This experiment was designed as a randomized complete block with four replications. Pots were considered the experimental unit. Variation was partitioned into $\mathrm{P}$ treatment, day, and replicate main effects, and the $\mathrm{P}$ treatment $\times$ day interaction. Where F-tests were significant, $(P \leq 0.05)$, differences among the treatment means were determined using least significant difference (LSD, $P \leq 0.05$ ) (Snedecor and Cochran, 1980). All statistical analyses were conducted using SAS (SAS Institute, 1999).

\section{RESULTS AND DISCUSSION}

\section{Tissue Phosphorus Concentrations}

As expected, the minus-N Hoagland's solution modified to contain different $\mathrm{P}$ concentrations altered $\mathrm{P}$ concentrations in alfalfa root and shoot tissues. The $\mathrm{P}$ and day main effects, and $\mathrm{P} \times$ day interaction, were significant for $\mathrm{P}$ concentrations of root bark, wood, and fine roots (Figure 1). Phosphorus concentrations of fine roots and root bark tissues were similar at all P levels on day 7, when P treatments were initially applied, whereas P concentrations of root wood tissues of plants fertilized with $2 \mathrm{mM} P$ were slightly higher than the other treatments on day -7 . By day -5 , $\mathrm{P}$ concentrations in fine roots of plants supplied with 2 and $6 \mathrm{mM}$ P significantly increased when compared with fine roots of plants provided with no P. Bark and wood tissues of plants provided with 2 and $6 \mathrm{mM}$ P exhibited significant increases in P concentration by days -2 (wood) or 0 (bark; day of defoliation), and these differences relative to the no-P treatment were maintained for the duration of the study. Phosphorus concentrations in root tissues of plants provided with $0.25 \mathrm{mM} \mathrm{P}$ were similar to plants provided with $0 \mathrm{mM} \mathrm{P}$ prior to defoliation on day 0 , but increased in root wood beginning on day 2. The rapid acquisition of $\mathrm{P}$ in roots of plants provided with 2 and $6 \mathrm{mM} P$ agrees with the previous results, in which root $\mathrm{P}$ concentrations increased within $7 \mathrm{~d}$ of applying $6.0 \mathrm{mM} P$ to established alfalfa plants (Li et al., 1998). In addition, the more rapid increase in fine-root $\mathrm{P}$ concentration relative to the other root tissues suggests, but does not prove, that fine roots acquire $\mathrm{P}$ prior to other root tissues.

A slight decline in bark P concentration of plants provided with 2 and $6 \mathrm{mM} \mathrm{P}$ occurred after defoliation on day 0 and continued until day 2. Thereafter, bark P concentration increased and exceeded pre-defoliation concentrations by day 9 for these $\mathrm{P}$ treatments. This pattern of tissue $\mathrm{P}$ 
depletion and accumulation was also observed in wood tissues, but the change was only significant for the $2.0 \mathrm{mM} P$ treatment. We reported previously a decline in alfalfa root $\mathrm{P}$ concentration after defoliation and attributed this loss to mobilization of root P reserves (mainly phytate $\mathrm{P}$ ) to regrowing shoots (Li et al., 1998). Other plant species also store excess $\mathrm{P}$ in vacuoles and remobilize it during periods of $\mathrm{P}$ deficiency (Lee et al., 1990).

The $\mathrm{P}$ and day main effects and $\mathrm{P} \times$ day interaction were also significant for $\mathrm{P}$ concentrations in leaf and stem tissues (Figure 2). As expected, P concentrations of both tissues were unaffected by $\mathrm{P}$ treatment on day -7 , when $\mathrm{P}$ treatments were initially applied. By day -5 and later samplings, $\mathrm{P}$ concentrations in stems and leaves of plants provided with 2 and $6 \mathrm{mM} \mathrm{P}$ increased when compared with tissues of plants provided with $0 \mathrm{mM}$ P. In comparison, $\mathrm{P}$ concentrations in stems of plants provided with $0.25 \mathrm{mM} \mathrm{P}$ were generally similar to those observed for plants provided with 0mMP throughout the study, whereas $0.25 \mathrm{mMP}$ increased leaf $\mathrm{P}$ concentrations on day 9 for both regrowing shoots of cut plants and intact shoots of uncut plants.

The minimum $\mathrm{P}$ concentration at which symptoms of $\mathrm{P}$ deficiency start becoming noticeable is 0.2\%-0.3\% dry weight (Kunishi and Vickers, 1980). Our tissue P concentrations are expressed on a fresh-weight basis, so a direct comparison between our data and these critical concentrations cannot be made. However, if we estimate root water concentration at $80 \%$, root $\mathrm{P}$ concentrations at the onset of the study (day-7) would be less than $2.5 \mathrm{mg} \mathrm{g}^{-1}(0.25 \%)$ on a dry-weight basis (Haagenson, 2001). This low root-P concentration explains why shoot growth was very responsive to $\mathrm{P}$ application.

\section{Shoot and Root Dry-Weight Accumulation}

The $\mathrm{P}$ treatment and day main effects were significant for shoot dry weight (Figure 3). Seven days of $\mathrm{P}$ application resulted in a significant increase in shoot dry weight on day 0 for plants fertilized with 2 and $6 \mathrm{mM} P$ compared with the 0 and $0.25 \mathrm{mM} P$ treatments. On day 9 of regrowth, shoot mass of all $\mathrm{P}$ treatments was greater than that of plants provided with $0 \mathrm{mM} \mathrm{P}$, with shoot mass of plants provided with $6 \mathrm{mM} P$ exceeding that of the 0.25 and $2 \mathrm{mM} \mathrm{P}$ treatments. The P treatment was significant for root dry-weight accumulation (Figure 3) on day 
9. Root mass of plants provided with $0.25 \mathrm{mM} \mathrm{P}$ was greater than that of the other treatments, even exceeding that of the $6.0 \mathrm{mMP}$ treatment.

Plants starved for P grow more slowly and appear stunted when compared with plants grown in P-rich media. Phosphorus deficiency reduced alfalfa shoot growth by reducing shoots per plant and mass per shoot (Li et al., 1998). Sanderson and Jones (1993) observed larger plants with more shoots per plant when alfalfa stands were fertilized with $\mathrm{P}$ in the field. This result agrees with our current working hypothesis that greater $\mathrm{P}$ fertility promotes bigger, healthier, and fasterregrowing alfalfa plants that eliminate weak neighboring plants. Berg et al. (2005) recently reported that $\mathrm{P}$ enhanced yield of alfalfa by enhancing the mass of individual shoots, while not altering the number of shoots per plant.

It was surprising to learn that plants provided with $0.25 \mathrm{mM} \mathrm{P}$ had the highest root dry weight at the end of the experiment (day 9). The lower root mass with 2 and $6 \mathrm{mM} \mathrm{P}$ may have been due to loss of root mass associated with depletion of root TNC and N pools in response to P-enhanced shoot regrowth rates (Li et al., 1998). In addition, fine root tissues proliferated at the end of the taproot in plants provided with 0 and $0.25 \mathrm{mM} \mathrm{P}$. Additional research is needed to document alfalfa root responses to low, sub-optimal P supply in order to better understand the potential adaptation of this species to low $\mathrm{P}$.

\section{Taproot Sugar and Starch Concentrations}

Both sugar and starch concentrations were assayed to determine how P nutrition and defoliation alter root carbohydrate reserve accumulation and use, which in turn impact shoot regrowth rate and forage yield. The $\mathrm{P}$ treatment and day main effects and $\mathrm{P}$ treatment $\times$ day interaction were significant for sugar concentrations in both bark and wood tissues of roots (Figure 4). The slightly higher sugar concentrations for the $0 \mathrm{mM}$ P treatment on day -7 when compared with the 2 and $6 \mathrm{mM}$ (bark) and $6 \mathrm{mM}$ (wood) treatments were probably not due to $\mathrm{P}$ application, because root tissues were sampled within minutes of $\mathrm{P}$ application. By day -5 , sugar concentrations were lower in root tissues of plants provided with $6 \mathrm{mMP}$, and by days -2 and 0 sugar levels were significantly lower in roots of plants provided with 2 and $6 \mathrm{mMP}$ when compared with plants provided with $0 \mathrm{mM}$ P. There was a significant defoliation-induced decline in both wood and 
bark sugar concentrations, irrespective of $\mathrm{P}$ treatment, between day 0 (day of herbage removal) and day 1. Root sugar levels continued to decline for the $0 \mathrm{mM} P$ treatment between days 1 and 2, while no change in root sugar concentrations was observed for the other P treatments in either wood or bark tissues. From days 2 to 6 after defoliation, therewas a general increase in sugar concentrations in both tissues irrespective of $\mathrm{P}$ treatment. From days 6 to 9 after defoliation, only plants provided with $2 \mathrm{mM}$ P significantly increased in both wood and bark sugar concentrations. Sugar concentrations in roots of P-fertilized plants that were left uncut were impacted by $\mathrm{P}$ treatment. Bark sugar concentrations were reduced significantly in plants provided any rate of $\mathrm{P}$, whereas only the $6 \mathrm{mM}$ P treatment reduced sugar concentrations in root wood tissues of uncut plants on day 9 .

Sucrose, glucose, and fructose concentrations in roots of P-deficient plants have been reported to be two to three times higher than those of plants provided with normal levels of P (Fredeen et al., 1989). Huber and Israel (1982) suggested that higher sucrose levels were associated with higher activity of sucrose synthetic enzymes in soybean (Glycine max (L.) Merr.) plants, leading to low starch concentration. Our results agree with previous P-fertility studies with alfalfa, in which a significant decline in sugar concentrations was observed in taproots of plants provided with 0.25 and $6 \mathrm{mMP}$ (Li et al., 1998). Application of 2 and $6 \mathrm{mM}$ P stimulated shoot growth by day 0 (Figure 3); this response was associated with a P-induced reduction in sugar concentration in taproot tissues of these plants, and the inability of taproot starch hydrolysis to rapidly replenish sugar pools.

The P treatment and day main effects were significant for wood starch concentration; however, there were no significant $\mathrm{P}$ treatment or day effects for bark starch concentration (Figure 5). For reasons we do not understand, starch concentrations were significantly lower in root wood tissues of P-treated plants when they were initially fertilized with $\mathrm{P}$ on day -7 . These differences between $\mathrm{P}$ treatments were not observed on days $-5,-2$, or day 0 when herbage on plants was removed. One day after defoliation, there was a significant decline in the wood starch concentrations of plants supplied with 0.25 and $6 \mathrm{mM}$ P. Plants receiving $6 \mathrm{mM} \mathrm{P}$ also had lower wood starch concentrations on day 2 when compared with unfertilized plants. Thereafter, plants provided with 2 or $6 \mathrm{mM} P$ had lower wood starch concentrations than did plants provided with 
$2780 \mathrm{mM}$ P. Wood starch concentrations of plants left uncut during the $9 \mathrm{~d}$ regrowth period were

279 only slightly reduced (at the $2 \mathrm{mM}$ level) by $\mathrm{P}$ treatment.

280

281

282

283

284

285

286

287

288

289

290

291

292

293

294

295

296

297

298

299

300

301

302

303

304

305

306

307

A reduction in taproot wood starch concentration in defoliated plants provided with 2 or $6 \mathrm{mM}$ agrees with previous results with alfalfa where concentrations of starch declined in alfalfa taproots during the $10 \mathrm{~d}$ after defoliation, as new shoots developed on crowns (Li et al., 1998). These authors showed that $\mathrm{P}$ deficiency impaired root starch mobilization after defoliation and with it, shoot regrowth rate. In this study, the limited starch hydrolysis of P-fertilized plants was associated with low root sugar concentrations.

Phosphorus deficiency has been shown in other studies to increase tissue starch concentrations. Huber and Israel (1982) found that sucrose-P synthetase activity decreased by $27 \%$ in P-deprived soybean plants, and this reduction in enzyme activity was negatively correlated with starch accumulation. The increase in starch concentration in the leaves of P-deficient plants was accompanied by a $45 \%$ increase in total activity of ADPG pyrophosphorylase, a key regulatory enzyme involved in starch synthesis. These results agree with previous studies that found that when cytosolic P levels are low, triose-P will be trapped in plastids and transport of carbohydrates from chloroplasts to sinks (such as roots or seeds) will be reduced, leading to starch accumulation in leaves (Fredeen et al., 1989). These data confirm that, although starch accumulation in source tissues is generally promoted by $\mathrm{P}$-deficiency, inadequate $\mathrm{P}$ impairs utilization of this $\mathrm{C}$ reserve.

\section{Taproot Amino Acid and Protein Concentrations}

Several studies have confirmed that alfalfa roots accumulate substantial quantities of $\mathrm{N}$ in the form of protein and amino acids that supply $\mathrm{N}$ to regrowing shoots during the initial 10 to $14 \mathrm{~d}$ after herbage removal (Volenec et al., 1996). In our study, the P treatment and day main effects and $\mathrm{P} \times$ day interaction were significant for both bark and wood amino acid concentrations (Figure 6). Amino acid concentrations in bark and wood tissues of plants were similar on day -7, when $\mathrm{P}$ treatments were initially applied. No effect of $\mathrm{P}$ treatment was apparent on day -5 , but amino acid concentrations were lower in bark tissues of plants provided with 2 and $6 \mathrm{mM} P$ and 
in wood tissues of plants provided with $\mathrm{P}$ at any concentration on day -2 . Amino acid concentrations continued to decline in wood tissues of plants provided with $0.25,2$, and $6 \mathrm{mM}$ $\mathrm{P}$ on day 0 ; however, bark amino acid concentrations on day 0 were lower only for plants supplied with $2 \mathrm{mM}$ P. Beginning on day 1, significant decreases in amino acid concentrations were found in bark and wood tissues of plants provided with 2 and $6 \mathrm{mM}$ P; this difference extended to the $0.25 \mathrm{mM} \mathrm{P}$ treatment by day 9 . Amino-acid concentrations of both root tissues were markedly lower in P-fertilized plants that were left uncut on day 9, indicating a large influence of $\mathrm{P}$ fertility on taproot amino acid mobilization to regrowing shoots.

Only the Day main effect was significant for both bark and wood protein concentrations (Figure 7). There was a significant increase in both bark and wood protein concentrations from day -7 to day -5 . From day-5 to day 0 , bark protein concentrations remained unchanged, while wood protein continued to increase to day-2. A slight decline in wood protein concentration occurred 1 $\mathrm{d}$ after defoliation, followed by an increase on day 2. Wood protein declined again on day 6 , but was followed by an increase on day 9 . Bark protein concentration increased gradually from day 1 to 9 .

Several studies have critically evaluated the role of taproot $\mathrm{N}$ pools in regrowth and stress tolerance of alfalfa. For example, Vance et al. (1979) reported that $\mathrm{N}_{2}$ fixation of alfalfa declined $88 \%$ within $24 \mathrm{~h}$ following defoliation and remained low for $13 \mathrm{~d}$. Mobilization of root $\mathrm{N}$ to regrowing shoots is necessary during early shoot regrowth to meet the $\mathrm{N}$ needs of developing shoots. Previous studies using $15 \mathrm{~N}$ labeling have shown that both amino acid and protein pools provide shoot $\mathrm{N}$ needs during regrowth (Barber et al., 1995). Other studies have shown a consistent pattern of root protein and amino-acid depletion during the two weeks after herbage removal, followed by restoration during the last two weeks of shoot regrowth (Volenec et al., 1996). A previous study of the effects of $P$ on alfalfa root-protein mobilization, using weekly sampling, with revealed more extensive protein depletion from roots of $\mathrm{P}$ fertilized plants when compared with P-deficient alfalfa (Li et al., 1998). While the short-term sampling used in this experiment likely obscured defoliation induced changes in root protein pools, reductions in the amino acid pool occurred as expected and were more extensive in the rapidly regrowing Pfertilized plants. 


\section{Phosphorus-Transporter Transcript Levels}

341 Northern blot analysis was used to determine steady-state transcript level for P-transporters in

342 various alfalfa tissues, and to characterize howtranscript abundance was altered by P. Transcript

343 levels were assayed using the high-affinity P-transporter cDNA isolated from Medicago sativa as

344 a probe (MsPT1; accession number AY366351). Contrary to our expectations, transcript for this

345 high-affinity P-transporter was not detected in any tissue assayed, irrespective of defoliation or

346 P-treatment (data not shown). To verify the ability of this cDNA to detect transcript for the high-

347 affinity P-transporter, we conducted Northern analyses using RNA from a separate P-nutrition

348 experiment. As expected, transcript for the high-affinity P-transporter was high in suspension

349 cells grown in P-depleted media, and declined rapidly as cells were transferred to media

350 containing high P levels (Abu Qamar et al., 2005). While steady-state transcript levels for this

351 high-affinity P-transporter can be enhanced under P limiting conditions, significant

352 inconsistencies exist that will require additional research in order to understand the role of these

353 putative transporters in P uptake by soil-grown alfalfa. Previous experiments were conducted

354 using cell cultures, hydroponics, or aeroponics (Muchhal and Raghothama, 1999; Leggewie et

355 al., 1997). These differences in growth media could contribute to the contrasting results seen in

356 the present greenhouse studies compared with previous work.

357

\section{REFERENCES}

359 Abu Qamar, S. F., T. G. Sors, S. M. Cunningham, B. C. Joern, and J. J. Volenec 2005. Phosphate nutrition effects on growth, phosphate transporter transcript levels and physiology of alfalfa cells. Plant Cell Tissue and Organ Culture 82: 131-140.

Barber, L. D., B. C. Joern, and J. J. Volenec. 1995. Effect of supplemental nitrogen on nitrogen uptake and remobilization during early alfalfa regrowth. Lexington, KY: Proceedings of the American Forage and Grassland Council. 
368

369

370

371

372

373

374

375

376

377

378

379

380

381

382

383

384

385

386

387

388

389

390

391

392

393

394

395

396

397

398

Bradford, M. M. 1976. A rapid and sensitive method for the quantification of microgram quantities of protein utilizing the principle protein dye binding. Analytical Biochemistry 72: $248-254$.

Brooks, A. 1986. Effects of phosphorus nutrition on ribulose-1,5-bisphosphate carboxylase activation, photosynthetic quantum yield and amounts of some Calvin-Cycle metabolites in spinach leaves. Australian Journal of Plant Physiology 13: 221-237.

Chen, P. S., T. Y. Toribara, and H. Warner. 1956. Microdetermination of phosphorus. Analytical Chemistry 28: 1756-1758.

Cunningham, S. M., and J. J. Volenec. 1996. Purification and characterization of vegetative storage proteins from alfalfa (Medicago sativa L.). Journal of Plant Physiology 47: 625-632.

Cunningham, S. M., and J. J.Volenec. 1998. Seasonal carbohydrate and nitrogen metabolism in roots of contrasting alfalfa (Medicago sativa L.) cultivars. Journal of Plant Physiology 153: $220-225$.

Drew, M. C., and L. R. Saker. 1984. Uptake and long-distance transport of phosphate, potassium and chloride in relation to internal ion concentration in barley: Evidence of non-allosteric regulation. Planta 160: 500-507.

Feinberg, A. P., and B. Volgestein. 1983. A technique for radiolabeling DNA restriction endonuclease fragments to high specific activity. Analytical Biochemistry 132: 6-13.

Fredeen, A. L., I. M. Rao, and N. Terry. 1989. Influence of phosphorus nutrition on growth and carbon partitioning in Glycine max. Plant Physiology 89: 225-230.

Gana, J. A., N. E. Kalengamaliro, S. M. Cunningham, and J. J. Volenec. 1998. Expression of beta-amylase from alfalfa taproots. Plant Physiology 118: 1495-1505.

Haagenson, D. M. 2001. Physiological analysis of alfalfa (Medicago sativa L.) winter hardiness among cultivars exhibiting contrasting fall dormancy, Ph.D. diss., Purdue University.

Hoagland, D. R., and D. I. Arnon. 1950. The water culture method for growing plants without soil, Circular 347. Berkeley, CA: California Agricultural Experiment Station.

Huber, S. C., and D. W. Israel. 1982. Biochemical basis for partitioning of photosynthetically fixed carbon between starch and sucrose in soybean (Glycine max L. Merr.) leaves. Plant Physiology 69: 691-696.

Koehler, L. H. 1952. Differentiation of carbohydrates by anthrone reaction rate and color intensity. Analytical Chemistry 24: 1576-1579. 
Kunishi, H. M., and J. C. Vickers. 1980. Adsorption and phosphorus requirements of acid soils. Soil Science 129(1): 28-35.

Lee, R. B., R. G. Ratcliffe, and T. E. Southon. 1990. 31P-NMR measurements of the cytoplasmic and vacuolar Pi content of mature maize roots: Relationships with phosphorus status and phosphate fluxes. Journal of Experimental Botany 41: 1063-1078.

Leggewie, G., L. Willmitzer, and J. W. Riesmeier. 1997. Two cDNA from potato are able to complement a phosphate uptake-deficient yeast mutant: Identification of phosphate transporters from higher plants. Plant Cell 9: 381-392.

Lehrach, H., D. Diamond, J. M.Wozney, and H. Boedtker. 1977. RNA molecular weight determination by electrophoresis under denaturing conditions, a critical reexamination. Biochemistry 16: 4743-4751.

Li, R., J. J. Volenec, B. C. Joern, and S. M. Cunningham. 1998. Effects of phosphorus nutrition on carbohydrate and protein metabolism in alfalfa roots. Journal of Plant Nutrition 21: 459474.

Liu, C., U. S. Muchhal, M. Uthappa, A. K.Kononowicz, and K. G. Raghothama. 1998a. Tomato phosphate transporter genes are differentially regulated in plant tissues by phosphorus. Plant Physiology 116: 91-99.

Liu, H., A. T. Trieu, L. A. Blaylock, and M. J. Harrison. 1998b. Cloning and characterization of two phosphate transporters from Medicago truncatula roots: Regulation in response to phosphate and to colonization by arbuscular mycorrhizal (AM) fungi. Molecular Plant Microbe Interaction 11(1): 14-22.

Muchhal, U. S., and K. G. Raghothama. 1999. Transcriptional regulation of plant phosphate transporters. Proceedings of the National Academy of Science (USA) 96: 5868-5872.

Rao, I. M., A. L. Fredeen, and N. Terry. 1990. Leaf phosphate status, photosynthesis, and carbon partitioning in sugarbeet. III. Diurnal changes in carbon partitioning and carbon export. Plant Physiology 92: 29-36.

Rosen, H. 1957. A modified ninhydrin colorimetric analysis for amino acids. Archives of Biochemistry and Biophysics 67: 10-15.

Rufty, W. T., D. W. Israel, R. J. Volk, J. Qiu, and T. Sa. 1993. Phosphate regulation of nitrate assimilation in soybean. Journal of Experimental Botany 44: 879-891. 
429 Sanderson, M. A., and R. M. Jones. 1993. Stand dynamics and yield components of alfalfa as $430 \quad$ affected by phosphorus fertility. Agronomy Journal 85: 241-246.

431 SAS Institute. 1999. The SAS system for Windows, Release 8.0. Cary, NC: SAS Institute.

432 Smith, F. W., P. M. Ealing, B. Dong, E. Delhaize, and D. T. Clarkson. 1997. The cloning of two 433 Arabidopsis genes belonging to phosphate transporter family. Plant Journal 11: 83-92.

434 Snedecor, G. W., and W. G. Cochran. 1980. Statistical methods, 7th ed. Ames, Iowa: IA State $435 \quad$ University Press.

436 Vance, C. P., G. H. Heichel, D. K. Barnes, J.W. Bryan, and L. E. Johnson. 1979. Nitrogen

437 fixation, nodule development, and vegetative regrowth of alfalfa (Medicago sativa L.)

438 following harvest. Plant Physiology 64: 1-8.

439 Volenec, J. J., A. Ourry, and B. C. Joern. 1996. A role for nitrogen reserves in forage regrowth $440 \quad$ and stress tolerance. Physiologia Plantarum 97: 185-193.

441

442

443

444

445

446

447

448

449

450

451

452

453

454

455

456

457

458

459 


\section{Figure legend}

Figure 1. Concentrations (fresh weight basis) of $\mathrm{P}$ in bark, wood, and fine root tissues of alfalfa in response to $\mathrm{P}$ fertilization. Data are means of four replicates. The least significant difference (LSD) is provided at the $5 \%$ level of probability.

Figure 2. Concentrations (fresh weight basis) of $\mathrm{P}$ in leaf and stem tissues of alfalfa in response to $\mathrm{P}$ fertilization. Data are means of four replicates. The least significant difference (LSD) is provided at the $5 \%$ level of probability.

Figure 3. Dry weight of alfalfa shoots on days 0 and 9 and roots on day 9 as influenced by $P$ concentration. Data are means of four replicates. The least significant difference (LSD) is provided at the $5 \%$ level of probability.

Figure 4. Concentrations (fresh weight basis) of sugar in bark andwood tissues of alfalfa in response to $\mathrm{P}$ fertilization. Data are means of four replicates. The least significant difference (LSD) is provided at the $5 \%$ level of probability.

Figure 5. Concentrations (fresh weight basis) of starch in bark and wood tissues of alfalfa in response to $\mathrm{P}$ fertilization. Data are means of four replicates. Phosphorus treatments are designated as shown in Figure 4. The least significant difference (LSD) is provided at the 5\% level of probability. (ns = not significant).

Figure 6. Concentrations (fresh weight basis) of amino acids in bark and wood tissues of alfalfa roots in response to $\mathrm{P}$ fertilization. Data are means of four replicates. The least significant difference (LSD) is provided at the $5 \%$ level of probability.

Figure 7. Concentrations (fresh weight basis) of buffer-soluble proteins in bark and wood tissues of alfalfa roots in response to $\mathrm{P}$ fertilization. Data are means of four replicates and were averaged over P treatments for presentation. The least significant difference (LSD) is provided at the 5\% level of probability. 